\title{
Chemerin receptors (version 2019.4) in the IUPHAR/BPS Guide to Pharmacology Database
}

Anthony P. Davenport ${ }^{1}$ and Amy E. Monaghan ${ }^{2}$

1. University of Cambridge, UK

2. University of Edinburgh, UK

\begin{abstract}
Nomenclature for the chemerin receptors is presented as recommended by NC-IUPHAR [14, 41]). The chemoattractant protein and adipokine, chemerin, has been shown to be the endogenous ligand for both chemerin family receptors. Chemerin ${ }_{1}$ was the founding family member, and whenGPR1 was de-orphanised it was re-named Chermerin 2 [41]. Chemerin ${ }_{1}$ is also activated by the lipid-derived, anti-inflammatory ligand resolvin $\mathrm{E} 1$ (RvE1), which is formed via the sequential metabolism of EPA by aspirin-modified cyclooxygenase and lipoxygenase [2, 3]. In addition, two GPCRs for resolvin D1 (RvD1) have been identified: FPR2/ALX, the lipoxin $A_{4}$ receptor, and GPR32, an orphan receptor [43].
\end{abstract}

\section{Contents}

This is a citation summary for Chemerin receptors in the Guide to Pharmacology database (GtoPdb). It exists purely as an adjunct to the database to facilitate the recognition of citations to and from the database by citation analyzers. Readers will almost certainly want to visit the relevant sections of the database which are given here under database links.

GtoPdb is an expert-driven guide to pharmacological targets and the substances that act on them. GtoPdb is a reference work which is most usefully represented as an on-line database. As in any publication this work should be appropriately cited, and the papers it cites should also be recognized. This document provides a citation for the relevant parts of the database, and also provides a reference list for the research cited by those parts.

Please note that the database version for the citations given in GtoPdb are to the most recent preceding version in which the family or its subfamilies and targets were substantially changed. The links below are to the current version. If you need to consult the cited version, rather than the most recent version, please contact the GtoPdb curators.

\section{Database links}

Chemerin receptors

http://www.guidetopharmacology.org/GRAC/FamilyDisplayForward?familyld=338

Receptors

Chemerin $_{1}$ (chemerin receptor 1 )

http://www.guidetopharmacology.org/GRAC/ObjectDisplayForward?objectld=79 
Chemerin $_{2}$ (chemerin receptor 2)

http://www.guidetopharmacology.org/GRAC/ObjectDisplayForward?objectld=82

\section{References}

1. Albanesi C, Scarponi C, Pallotta S, Daniele R, Bosisio D, Madonna S, Fortugno P, Gonzalvo-Feo S, Franssen JD and Parmentier M et al.. (2009) Chemerin expression marks early psoriatic skin lesions and correlates with plasmacytoid dendritic cell recruitment. J. Exp. Med. 206: 249-58 [PMID:19114666]

2. Arita M, Bianchini F, Aliberti J, Sher A, Chiang N, Hong S, Yang R, Petasis NA and Serhan CN. (2005) Stereochemical assignment, antiinflammatory properties, and receptor for the omega-3 lipid mediator resolvin E1. J. Exp. Med. 201: 713-22 [PMID:15753205]

3. Arita M, Ohira T, Sun YP, Elangovan S, Chiang N and Serhan CN. (2007) Resolvin E1 selectively interacts with leukotriene B4 receptor BLT1 and ChemR23 to regulate inflammation. J. Immunol. 178: 3912-7 [PMID:17339491]

4. Barnea G, Strapps W, Herrada G, Berman Y, Ong J, Kloss B, Axel R and Lee KJ. (2008) The genetic design of signaling cascades to record receptor activation. Proc. Natl. Acad. Sci. U.S.A. 105: 64-9 [PMID:18165312]

5. Bauer S, Wanninger J, Schmidhofer S, Weigert J, Neumeier M, Dorn C, Hellerbrand C, Zimara N, Schäffler A and Aslanidis $C$ et al.. (2011) Sterol regulatory element-binding protein 2 (SREBP2) activation after excess triglyceride storage induces chemerin in hypertrophic adipocytes. Endocrinology 152: 26-35 [PMID:21084441]

6. Berg V, Sveinbjörnsson B, Bendiksen S, Brox J, Meknas K and Figenschau Y. (2010) Human articular chondrocytes express ChemR23 and chemerin; ChemR23 promotes inflammatory signalling upon binding the ligand chemerin(21-157). Arthritis Res. Ther. 12: R228 [PMID:21192818]

7. Bondue B, Vosters O, de Nadai P, Glineur S, De Henau O, Luangsay S, Van Gool F, Communi D, De Vuyst $P$ and Desmecht $D$ et al.. (2011) ChemR23 dampens lung inflammation and enhances anti-viral immunity in a mouse model of acute viral pneumonia. PLoS Pathog. 7: e1002358 [PMID:22072972]

8. Bondue B, Wittamer V and Parmentier M. (2011) Chemerin and its receptors in leukocyte trafficking, inflammation and metabolism. Cytokine Growth Factor Rev. 22: 331-8 [PMID:22119008]

9. Bozaoglu K, Bolton K, McMillan J, Zimmet P, Jowett J, Collier G, Walder K and Segal D. (2007) Chemerin is a novel adipokine associated with obesity and metabolic syndrome. Endocrinology 148: 4687-94 [PMID:17640997]

10. Cash JL, Christian AR and Greaves DR. (2010) Chemerin peptides promote phagocytosis in a ChemR23and Syk-dependent manner. J. Immunol. 184: 5315-24 [PMID:20363975]

11. Cash JL, Hart R, Russ A, Dixon JP, Colledge WH, Doran J, Hendrick AG, Carlton MB and Greaves DR. (2008) Synthetic chemerin-derived peptides suppress inflammation through ChemR23. J. Exp. Med. 205: 767-75 [PMID:18391062]

12. Coetzer M, Nedellec R, Cilliers T, Meyers T, Morris L and Mosier DE. (2011) Extreme genetic divergence is required for coreceptor switching in HIV-1 subtype C. J. Acquir. Immune Defic. Syndr. 56: 9-15 [PMID:20921899]

13. Croitoru-Lamoury J, Guillemin GJ, Boussin FD, Mognetti B, Gigout LI, Chéret A, Vaslin B, Le Grand R, Brew BJ and Dormont D. (2003) Expression of chemokines and their receptors in human and simian astrocytes: evidence for a central role of TNF alpha and IFN gamma in CXCR4 and CCR5 modulation. Glia 41: 354-70 [PMID:12555203]

14. Davenport AP, Alexander SP, Sharman JL, Pawson AJ, Benson HE, Monaghan AE, Liew WC, Mpamhanga CP, Bonner Tl and Neubig RR et al.. (2013) International Union of Basic and Clinical Pharmacology. LXXXVIII. G protein-coupled receptor list: recommendations for new pairings with cognate ligands. Pharmacol. Rev. 65: 967-86 [PMID:23686350]

15. De Palma G, Castellano G, Del Prete A, Sozzani S, Fiore N, Loverre A, Parmentier M, Gesualdo L, Grandaliano $G$ and Schena FP. (2011) The possible role of ChemR23/Chemerin axis in the recruitment of dendritic cells in lupus nephritis. Kidney Int. 79: 1228-35 [PMID:21346723] 
16. Demoor T, Bracke KR, Dupont LL, Plantinga M, Bondue B, Roy MO, Lannoy V, Lambrecht BN, Brusselle GG and Joos GF. (2011) The role of ChemR23 in the induction and resolution of cigarette smoke-induced inflammation. J. Immunol. 186: 5457-67 [PMID:21430224]

17. Doyle JR, Krishnaji ST, Zhu G, Xu ZZ, Heller D, Ji RR, Levy BD, Kumar K and Kopin AS. (2014) Development of a membrane-anchored chemerin receptor agonist as a novel modulator of allergic airway inflammation and neuropathic pain. J. Biol. Chem. 289: 13385-96 [PMID:24659779]

18. Du XY and Leung LL. (2009) Proteolytic regulatory mechanism of chemerin bioactivity Acta Biochim. Biophys. Sin. (Shanghai) 41: 973-9 [PMID:20011981]

19. Edinger AL, Hoffman TL, Sharron M, Lee B, O'Dowd B and Doms RW. (1998) Use of GPR1, GPR15, and STRL33 as coreceptors by diverse human immunodeficiency virus type 1 and simian immunodeficiency virus envelope proteins. Virology 249: 367-78 [PMID:9791028]

20. Edinger AL, Mankowski JL, Doranz BJ, Margulies BJ, Lee B, Rucker J, Sharron M, Hoffman TL, Berson JF, Zink MC, Hirsch VM, Clements JE and Doms RW. (1997) CD4-independent, CCR5-dependent infection of brain capillary endothelial cells by a neurovirulent simian immunodeficiency virus strain. Proc. Natl. Acad. Sci. U.S.A. 94: 14742-7 [PMID:9405683]

21. Eisinger K, Bauer S, Schäffler A, Walter R, Neumann E, Buechler C, Müller-Ladner U and Frommer KW. (2012) Chemerin induces CCL2 and TLR4 in synovial fibroblasts of patients with rheumatoid arthritis and osteoarthritis. Exp. Mol. Pathol. 92: 90-6 [PMID:22037282]

22. Ernst MC, Haidl ID, Zúñiga LA, Dranse HJ, Rourke JL, Zabel BA, Butcher EC and Sinal CJ. (2012) Disruption of the chemokine-like receptor-1 (CMKLR1) gene is associated with reduced adiposity and glucose intolerance. Endocrinology 153: 672-82 [PMID:22186410]

23. Ernst MC, Issa M, Goralski KB and Sinal CJ. (2010) Chemerin exacerbates glucose intolerance in mouse models of obesity and diabetes. Endocrinology 151: 1998-2007 [PMID:20228173]

24. Farzan M, Choe H, Martin K, Marcon L, Hofmann W, Karlsson G, Sun Y, Barrett P, Marchand N, Sullivan N, Gerard N, Gerard C and Sodroski J. (1997) Two orphan seven-transmembrane segment receptors which are expressed in CD4-positive cells support simian immunodeficiency virus infection. J. Exp. Med. 186: 405-11 [PMID:9236192]

25. Fredman G, Van Dyke TE and Serhan CN. (2010) Resolvin E1 regulates adenosine diphosphate activation of human platelets. Arterioscler. Thromb. Vasc. Biol. 30: 2005-13 [PMID:20702811]

26. Gabuzda D and Wang J. (1999) Chemokine receptors and virus entry in the central nervous system.J. Neurovirol. 5: 643-58 [PMID:10602405]

27. Gantz I, Konda Y, Yang YK, Miller DE, Dierick HA and Yamada T. (1996) Molecular cloning of a novel receptor (CMKLR1) with homology to the chemotactic factor receptors. Cytogenet. Cell Genet. 74: 286-90 [PMID:8976386]

28. Goralski KB, McCarthy TC, Hanniman EA, Zabel BA, Butcher EC, Parlee SD, Muruganandan S and Sinal CJ. (2007) Chemerin, a novel adipokine that regulates adipogenesis and adipocyte metabolism. J. Biol. Chem. 282: 28175-88 [PMID:17635925]

29. Goralski KB and Sinal CJ. (2009) Elucidation of chemerin and chemokine-like receptor-1 function in adipocytes by adenoviral-mediated shRNA knockdown of gene expression. Meth. Enzymol. 460: 289-312 [PMID:19446731]

30. Graham KL, Zabel BA, Loghavi S, Zuniga LA, Ho PP, Sobel RA and Butcher EC. (2009) Chemokine-like receptor-1 expression by central nervous system-infiltrating leukocytes and involvement in a model of autoimmune demyelinating disease. J. Immunol. 183: 6717-23 [PMID:19864606]

31. Graham KL, Zhang JV, Lewén S, Burke TM, Dang T, Zoudilova M, Sobel RA, Butcher EC and Zabel BA. (2014) A novel CMKLR1 small molecule antagonist suppresses CNS autoimmune inflammatory disease. PLOS ONE 9: e112925 [PMID:25437209]

32. Hart R and Greaves DR. (2010) Chemerin contributes to inflammation by promoting macrophage adhesion to VCAM-1 and fibronectin through clustering of VLA-4 and VLA-5. J. Immunol. 185: 3728-39 [PMID:20720202]

33. Haworth O, Cernadas M and Levy BD. (2011) NK cells are effectors for resolvin E1 in the timely resolution 
of allergic airway inflammation. J. Immunol. 186: 6129-35 [PMID:21515793]

34. Hiura H, Sugawara A, Ogawa H, John RM, Miyauchi N, Miyanari Y, Horiike T, Li Y, Yaegashi N, Sasaki H, Kono T and Arima T. (2010) A tripartite paternally methylated region within the Gpr1-Zdbf2 imprinted domain on mouse chromosome 1 identified by meDIP-on-chip. Nucleic Acids Res. 38: 4929-45 [PMID:20385583]

35. Ikeda K, Konishi K, Sato M, Hoshino H and Tanaka K. (2001) Inhibition of HIV-1 infection by synthetic

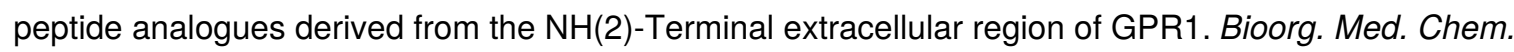
Lett. 11: 2607-9 [PMID:11551760]

36. Issa ME, Muruganandan S, Ernst MC, Parlee SD, Zabel BA, Butcher EC, Sinal CJ and Goralski KB. (2012) Chemokine-like receptor 1 regulates skeletal muscle cell myogenesis. Am. J. Physiol., Cell Physiol. 302: C1621-31 [PMID:22460713]

37. Iwata N, Yoshida H, Tobiume M, Ono F, Shimazaki T, Sata T and Nakajima N. (2007) Simian fetal brain progenitor cells for studying viral neuropathogenesis. J. Neurovirol. 13: 11-22 [PMID:17454444]

38. Joshi N, Johnson LL, Wei WQ, Abnet CC, Dong ZW, Taylor PR, Limburg PJ, Dawsey SM, Hawk ET and Qiao YL et al.. (2006) Gene expression differences in normal esophageal mucosa associated with regression and progression of mild and moderate squamous dysplasia in a high-risk Chinese population. Cancer Res. 66: 6851-60 [PMID:16818663]

39. Kang MK, Kameta A, Shin KH, Baluda MA, Kim HR and Park NH. (2003) Senescence-associated genes in normal human oral keratinocytes. Exp. Cell Res. 287: 272-81 [PMID:12837283]

40. Kaur J, Adya R, Tan BK, Chen J and Randeva HS. (2010) Identification of chemerin receptor (ChemR23) in human endothelial cells: chemerin-induced endothelial angiogenesis. Biochem. Biophys. Res. Commun. 391: 1762-8 [PMID:20044979]

41. Kennedy AJ and Davenport AP. (2018) International Union of Basic and Clinical Pharmacology CIII: Chemerin Receptors CMKLR1 (Chemerin1) and GPR1 (Chemerin2) Nomenclature, Pharmacology, and Function. Pharmacol. Rev. 70: 174-196 [PMID:29279348]

42. Kennedy AJ, Yang P, Read C, Kuc RE, Yang L, Taylor EJ, Taylor CW, Maguire JJ and Davenport AP. (2016) Chemerin Elicits Potent Constrictor Actions via Chemokine-Like Receptor 1 (CMKLR1), not GProtein-Coupled Receptor 1 (GPR1), in Human and Rat Vasculature. J Am Heart Assoc 5: [PMID:27742615]

43. Krishnamoorthy S, Recchiuti A, Chiang N, Yacoubian S, Lee CH, Yang R, Petasis NA and Serhan CN. (2010) Resolvin D1 binds human phagocytes with evidence for proresolving receptors. Proc. Natl. Acad. Sci. U.S.A. 107: 1660-5 [PMID:20080636]

44. Liu HY, Soda Y, Shimizu N, Haraguchi Y, Jinno A, Takeuchi Y and Hoshino H. (2000) CD4-Dependent and CD4-independent utilization of coreceptors by human immunodeficiency viruses type 2 and simian immunodeficiency viruses. Virology 278: 276-88 [PMID:11112502]

45. Luangsay S, Wittamer V, Bondue B, De Henau O, Rouger L, Brait M, Franssen JD, de Nadai P, Huaux F and Parmentier M. (2009) Mouse ChemR23 is expressed in dendritic cell subsets and macrophages, and mediates an anti-inflammatory activity of chemerin in a lung disease model. J. Immunol. 183: 6489-99 [PMID:19841182]

46. Maguire CA, Sapinoro R, Girgis N, Rodriguez-Colon SM, Ramirez SH, Williams J and Dewhurst S. (2006) Recombinant adenovirus type 5 vectors that target DC-SIGN, ChemR23 and alpha(v)beta3 integrin efficiently transduce human dendritic cells and enhance presentation of vectored antigens. Vaccine 24: 671-82 [PMID:16154247]

47. Marchese A, Cheng R, Lee MC, Porter CA, Heiber M, Goodman M, George SR and O'Dowd BF. (1994) Mapping studies of two $G$ protein-coupled receptor genes: an amino acid difference may confer a functional variation between a human and rodent receptor. Biochem. Biophys. Res. Commun. 205: 1952-8 [PMID:7811287]

48. Marchese A, Docherty JM, Nguyen T, Heiber M, Cheng R, Heng HH, Tsui LC, Shi X, George SR and O'Dowd BF. (1994) Cloning of human genes encoding novel G protein-coupled receptors. Genomics 23: 609-18 [PMID:7851889] 
49. Methner A, Hermey G, Schinke B and Hermans-Borgmeyer I. (1997) A novel G protein-coupled receptor with homology to neuropeptide and chemoattractant receptors expressed during bone development. Biochem. Biophys. Res. Commun. 233: 336-42 [PMID:9144535]

50. Mognetti B, Moussa M, Croitoru J, Menu E, Dormont D, Roques P and Chaouat G. (2000) HIV-1 coreceptor expression on trophoblastic cells from early placentas and permissivity to infection by several HIV-1 primary isolates. Clin. Exp. Immunol. 119: 486-92 [PMID:10691921]

51. Morehouse MG, Scheer BT and Deuel HJ. (1947) The effect of dietary fat level on the physical capacity of rats during undernutrition. Fed. Proc. 6: 415 [PMID:20343880]

52. Muruganandan S, Parlee SD, Rourke JL, Ernst MC, Goralski KB and Sinal CJ. (2011) Chemerin, a novel peroxisome proliferator-activated receptor gamma (PPARgamma) target gene that promotes mesenchymal stem cell adipogenesis. J. Biol. Chem. 286: 23982-95 [PMID:21572083]

53. Muruganandan S, Roman AA and Sinal CJ. (2010) Role of chemerin/CMKLR1 signaling in adipogenesis and osteoblastogenesis of bone marrow stem cells. J. Bone Miner. Res. 25: 222-34 [PMID:19929432]

54. Mårtensson UE, Bristulf J, Owman C and Olde B. (2005) The mouse chemerin receptor gene, mcmklr1, utilizes alternative promoters for transcription and is regulated by all-trans retinoic acid. Gene 350: 65-77 [PMID:15792532]

55. Mårtensson UE, Fenyö EM, Olde B and Owman C. (2006) Characterization of the human chemerin receptor--ChemR23/CMKLR1--as co-receptor for human and simian immunodeficiency virus infection, and identification of virus-binding receptor domains. Virology 355: 6-17 [PMID:16904155]

56. Mårtensson UE, Owman C and Olde B. (2004) Genomic organization and promoter analysis of the gene encoding the mouse chemoattractant-like receptor, CMKLR1. Gene 328: 167-76 [PMID:15019996]

57. Ohagen A, Devitt A, Kunstman KJ, Gorry PR, Rose PP, Korber B, Taylor J, Levy R, Murphy RL, Wolinsky SM and Gabuzda D. (2003) Genetic and functional analysis of full-length human immunodeficiency virus type 1 env genes derived from brain and blood of patients with AIDS. J. Virol. 77: 12336-45 [PMID:14581570]

58. Ohira T, Arita M, Omori K, Recchiuti A, Van Dyke TE and Serhan CN. (2010) Resolvin E1 receptor activation signals phosphorylation and phagocytosis. J. Biol. Chem. 285: 3451-61 [PMID:19906641]

59. Owman C, Lolait SJ, Santén S and Olde B. (1997) Molecular cloning and tissue distribution of cDNA encoding a novel chemoattractant-like receptor. Biochem. Biophys. Res. Commun. 241: 390-4 [PMID:9425281]

60. Parlee SD, Ernst MC, Muruganandan S, Sinal CJ and Goralski KB. (2010) Serum chemerin levels vary with time of day and are modified by obesity and tumor necrosis factor-\{alpha\}. Endocrinology 151: 2590602 [PMID:20363880]

61. Parolini S, Santoro A, Marcenaro E, Luini W, Massardi L, Facchetti F, Communi D, Parmentier M, Majorana A, Sironi M, Tabellini G, Moretta A and Sozzani S. (2007) The role of chemerin in the colocalization of NK and dendritic cell subsets into inflamed tissues. Blood 109: 3625-32 [PMID:17202316]

62. Rama D, Esendagli G and Guc D. (2011) Expression of chemokine-like receptor 1 (CMKLR1) on J744A.1 macrophages co-cultured with fibroblast and/or tumor cells: modeling the influence of microenvironment. Cell. Immunol. 271: 134-40 [PMID:21752353]

63. Reverchon M, Cornuau M, Ramé C, Guerif F, Royère D and Dupont J. (2012) Chemerin inhibits IGF-1induced progesterone and estradiol secretion in human granulosa cells. Hum. Reprod. 27: 1790-800 [PMID:22447628]

64. Rodriguez Parkitna J, Korostynski M, Kaminska-Chowaniec D, Obara I, Mika J, Przewlocka B and Przewlocki R. (2006) Comparison of gene expression profiles in neuropathic and inflammatory pain. J. Physiol. Pharmacol. 57: 401-14 [PMID:17033093]

65. Roh SG, Song SH, Choi KC, Katoh K, Wittamer V, Parmentier M and Sasaki S. (2007) Chemerin--a new adipokine that modulates adipogenesis via its own receptor. Biochem. Biophys. Res. Commun. 362: 10138 [PMID:17767914]

66. Samson M, Edinger AL, Stordeur P, Rucker J, Verhasselt V, Sharron M, Govaerts C, Mollereau C, Vassart G, Doms RW and Parmentier M. (1998) ChemR23, a putative chemoattractant receptor, is expressed in 
monocyte-derived dendritic cells and macrophages and is a coreceptor for SIV and some primary HIV-1 strains. Eur. J. Immunol. 28: 1689-700 [PMID:9603476]

67. Sell H, Laurencikiene J, Taube A, Eckardt K, Cramer A, Horrighs A, Arner P and Eckel J. (2009) Chemerin is a novel adipocyte-derived factor inducing insulin resistance in primary human skeletal muscle cells. Diabetes 58: 2731-40 [PMID:19720798]

68. Shimizu N, Soda Y, Kanbe K, Liu HY, Jinno A, Kitamura T and Hoshino H. (1999) An orphan G proteincoupled receptor, GPR1, acts as a coreceptor to allow replication of human immunodeficiency virus types 1 and 2 in brain-derived cells. J. Virol. 73: 5231-9 [PMID:10233994]

69. Shimizu N, Tanaka A, Oue A, Mori T, Apichartpiyakul C and Hoshino H. (2008) A short amino acid sequence containing tyrosine in the $\mathrm{N}$-terminal region of $\mathrm{G}$ protein-coupled receptors is critical for their potential use as co-receptors for human and simian immunodeficiency viruses. J. Gen. Virol. 89: 3126-36 [PMID:19008402]

70. Simmons G, Reeves JD, Hibbitts S, Stine JT, Gray PW, Proudfoot AE and Clapham PR. (2000) Coreceptor use by HIV and inhibition of HIV infection by chemokine receptor ligands. Immunol. Rev. 177: 112-26 [PMID:11138769]

71. Singh A, Besson G, Mobasher A and Collman RG. (1999) Patterns of chemokine receptor fusion cofactor utilization by human immunodeficiency virus type 1 variants from the lungs and blood. J. Virol. 73: 6680-90 [PMID:10400765]

72. Skrzeczyńska-Moncznik J, Stefańska A, Zabel BA, Kapińska-Mrowiecka M, Butcher EC and Cichy J. (2009) Chemerin and the recruitment of NK cells to diseased skin. Acta Biochim. Pol. 56: 355-60 [PMID:19543554]

73. Skrzeczyńska-Moncznik J, Wawro K, Stefańska A, Oleszycka E, Kulig P, Zabel BA, Sułkowski M, Kapińska-Mrowiecka M, Czubak-Macugowska M, Butcher EC and Cichy J. (2009) Potential role of chemerin in recruitment of plasmacytoid dendritic cells to diseased skin. Biochem. Biophys. Res. Commun. 380: 323-7 [PMID:19168032]

74. Southern C, Cook JM, Neetoo-Isseljee Z, Taylor DL, Kettleborough CA, Merritt A, Bassoni DL, Raab WJ, Quinn E and Wehrman TS et al.. (2013) Screening $\beta$-Arrestin Recruitment for the Identification of Natural Ligands for Orphan G-Protein-Coupled Receptors. J Biomol Screen 18: 599-609 [PMID:23396314]

75. Spiroglou SG, Kostopoulos CG, Varakis JN and Papadaki HH. (2010) Adipokines in periaortic and epicardial adipose tissue: differential expression and relation to atherosclerosis. J. Atheroscler. Thromb. 17: 115-30 [PMID:20145358]

76. Suzuki Y, Yamashita R, Shirota M, Sakakibara Y, Chiba J, Mizushima-Sugano J, Nakai K and Sugano S. (2004) Sequence comparison of human and mouse genes reveals a homologous block structure in the promoter regions. Genome Res. 14: 1711-8 [PMID:15342556]

77. Tanaka TS, Jaradat SA, Lim MK, Kargul GJ, Wang X, Grahovac MJ, Pantano S, Sano Y, Piao Y and Nagaraja $R$ et al.. (2000) Genome-wide expression profiling of mid-gestation placenta and embryo using a 15,000 mouse developmental cDNA microarray. Proc. Natl. Acad. Sci. U.S.A. 97: 9127-32 [PMID:10922068]

78. Taylor MW, Tsukahara T, McClintick JN, Edenberg HJ and Kwo P. (2008) Cyclic changes in gene expression induced by Peg-interferon alfa-2b plus ribavirin in peripheral blood monocytes (PBMC) of hepatitis $C$ patients during the first 10 weeks of treatment. $J$ Transl Med6: 66 [PMID:18986530]

79. Tokizawa S, Shimizu N, Hui-Yu L, Deyu F, Haraguchi Y, Oite T and Hoshino H. (2000) Infection of mesangial cells with HIV and SIV: identification of GPR1 as a coreceptor. Kidney Int. 58: 607-17 [PMID:10916084]

80. Uddin M and Levy BD. (2011) Resolvins: natural agonists for resolution of pulmonary inflammation.Prog. Lipid Res. 50: 75-88 [PMID:20887750]

81. Vermi W, Riboldi E, Wittamer V, Gentili F, Luini W, Marrelli S, Vecchi A, Franssen JD, Communi D, Massardi L, Sironi M, Mantovani A, Parmentier M, Facchetti F and Sozzani S. (2005) Role of ChemR23 in directing the migration of myeloid and plasmacytoid dendritic cells to lymphoid organs and inflamed skin. J. Exp. Med. 201: 509-15 [PMID:15728234] 
82. Vödrös D, Thorstensson R, Doms RW, Fenyö EM and Reeves JD. (2003) Evolution of coreceptor use and CD4-independence in envelope clones derived from SIVsm-infected macaques. Virology 316: 17-28 [PMID:14599787]

83. Wittamer V, Franssen JD, Vulcano M, Mirjolet JF, Le Poul E, Migeotte I, Brézillon S, Tyldesley R, Blanpain C, Detheux M, Mantovani A, Sozzani S, Vassart G, Parmentier M and Communi D. (2003) Specific recruitment of antigen-presenting cells by chemerin, a novel processed ligand from human inflammatory fluids. J. Exp. Med. 198: 977-85 [PMID:14530373]

84. Wittamer V, Grégoire F, Robberecht P, Vassart G, Communi D and Parmentier M. (2004) The C-terminal nonapeptide of mature chemerin activates the chemerin receptor with low nanomolar potency. J. Biol. Chem. 279: 9956-62 [PMID:14701797]

85. Wu X, Ye Y, Rosell R, Amos Cl, Stewart DJ, Hildebrandt MA, Roth JA, Minna JD, Gu J and Lin £t al.. (2011) Genome-wide association study of survival in non-small cell lung cancer patients receiving platinum-based chemotherapy. J. Natl. Cancer Inst. 103: 817-25 [PMID:21483023]

86. Yoshimura T and Oppenheim JJ. (2008) Chemerin reveals its chimeric nature.J. Exp. Med. 205: 2187-90 [PMID:18809717]

87. Zabel BA, Nakae S, Zúñiga L, Kim JY, Ohyama T, Alt C, Pan J, Suto H, Soler D, Allen SJ, Handel TM, Song CH, Galli SJ and Butcher EC. (2008) Mast cell-expressed orphan receptor CCRL2 binds chemerin and is required for optimal induction of IgE-mediated passive cutaneous anaphylaxis. J. Exp. Med. 205: 2207-20 [PMID:18794339]

88. Zabel BA, Ohyama T, Zuniga L, Kim JY, Johnston B, Allen SJ, Guido DG, Handel TM and Butcher EC. (2006) Chemokine-like receptor 1 expression by macrophages in vivo: regulation by TGF-beta and TLR ligands. Exp. Hematol. 34: 1106-14 [PMID:16863918]

89. Zabel BA, Silverio AM and Butcher EC. (2005) Chemokine-like receptor 1 expression and chemerindirected chemotaxis distinguish plasmacytoid from myeloid dendritic cells in human blood. J. Immunol. 174: 244-51 [PMID:15611246]

90. Zhang YJ, Dragic T, Cao Y, Kostrikis L, Kwon DS, Littman DR, KewalRamani VN and Moore JP. (1998) Use of coreceptors other than CCR5 by non-syncytium-inducing adult and pediatric isolates of human immunodeficiency virus type 1 is rare in vitro. J. Virol. 72: 9337-44 [PMID:9765485]

91. Zhao RJ and Wang H. (2011) Chemerin/ChemR23 signaling axis is involved in the endothelial protection by K(ATP) channel opener iptakalim. Acta Pharmacol. Sin. 32: 573-80 [PMID:21516134] 